\title{
Staged and Non-staged Anaerobic Filters: Microbial Activity Segregation, Hydrodynamic Behaviour and Performance
}

\author{
Madalena Alves, ${ }^{1}$ Alcina Pereira, ${ }^{1}$ Manuel Mota, ${ }^{1 *}$ Júlio M. Novais ${ }^{2} \&$ \\ Emer Colleran ${ }^{3}$ \\ ${ }^{1}$ Centro de Engenharia Biológica-IBQF, Universidade do Minho, 4700 Braga, Portugal \\ 2 Centro de Engenharia Biológica e Química, Instituto Superior Técnico, 1000 Lisboa, Portugal \\ ${ }^{3}$ Department of Microbiology, University College, Galway, Ireland
}

(Received 17 November 1997; revised version received 25 May 1998; accepted 12 June 1998)

\begin{abstract}
This work describes a comparative study of staged and non-staged anaerobic filters for treating a synthetic dairy waste under similar operating conditions. The effect of increasing the substrate concentration from 3 to $12 \mathrm{~g} \mathrm{COD}$ $\mathrm{dm}^{-3}$ at a constant hydraulic residence time (HRT) of 2 days was evaluated with respect to overall reactor performance, biogas production, volatile fatty acids profiles along the height, methanogenic and acidogenic activity distribution, and hydrodynamic behaviour. The potential maximum specific methanogenic activity against acetate, hydrogen, propionate and butyrate and the lactose specific activity were determined for sludge sampled from three different points in each reactor, under two operating conditions (influent COD of 3 and $9 \mathrm{~g}$ COD $\mathrm{dm}^{-3}$ ). Although all trophic groups involved in the anaerobic process were found throughout the reactors, it was possible to identify different specific sludges at different heights in both reactors. Performances of the two configurations were very similar under the operating conditions tested and the plug flow behaviour of the staged reactor was clearly reduced when the influent concentration increased from 3 to $9 \mathrm{~g} \mathrm{COD} \mathrm{dm}^{-3}$. (C) 1998 Society of Chemical Industry
\end{abstract}

J. Chem. Technol. Biotechnol. 73, 99-108 (1998)

Key words: Anaerobic filter; methanogenic activity; hydrodynamic studies; dairy waste

\section{NOTATION}

\section{AFI Non-staged digester}

AFII Staged digester

COD Chemical oxygen demand

D Longitudinal dispersion coefficient

HRT Hydraulic retention time

$J \quad$ Number of mixed tanks in the 'tanks in series model'

* To whom correspondence should be addressed.

Contract/grant sponsor: EU Human Capital and Mobility network; Contract/grant number: EXBCHRXCT 930262.

Contract/grant sponsor: FCT National Programme;

Contract/grant number: PEAM/SEL/517/95

\section{$L \quad$ Length \\ MRT Mean residence time \\ $u \quad$ Upflow velocity \\ VFA Volatile fatty acids \\ VS Volatile solids \\ VSS Volatile suspended solids}

$\beta \quad$ Fraction of dead volume of the plug flow zone in the compartmental flow model

$\tau \mathrm{a} 1, \tau \mathrm{a} 2$ Mean residence time in the first and second perfectly mixed zone in the compartmental flow model

$\tau p \quad$ Mean residence time of the plug flow zone in the compartmental flow model 


\section{INTRODUCTION}

The operation of staged reactors is described in the literature from a number of viewpoints. ${ }^{1-5}$ Removal of biogas from the early stages of substrate conversion was stated by Harper and Pohland ${ }^{2}$ to be a factor in protection against toxic gaseous products (ammonia, sulphide, and air), thereby improving conditions for methanogenesis in the later stages. These workers concluded that the removal of biogas maintained low levels of hydrogen, particularly during pulse loading, so favouring acetic and propionic acid removal in the later stages.

Staged processes provide an optimal environment for degradation of intermediates, such as propionate, which may be particularly useful for thermophilic processes, but also for mesophilic treatment. ${ }^{6}$ More recently Lettinga $e t$ al. stated that the type and sequence of stages should be optimised, according to each specific application. $^{7}$

Enhanced stability of a thermophilic treatment system was achieved by Van Lier et al. ${ }^{4}$ using a staged process in an Upflow Staged Sludge Bed (USSB). In the last compartment, a very low volatile fatty acid concentration and a low hydrogen partial pressure were obtained. These authors also reported that staged degradation led to a segregation of biomass in terms of its biological and physical properties. ${ }^{8}$ Guiot et al. ${ }^{5}$ described the operation of a full scale multiplate anaerobic digester with a large capacity for solid retention, and Grobicki and Stuckey ${ }^{3}$ found that formate was an important intermediate in the anaerobic baffled reactor.

Although there is in the literature several references to staged systems, the application to fixed bed digesters is not vast. El-Shafie and Bloodgood ${ }^{1}$ studied the degradation of a synthetic complex wastewater in a staged anaerobic filter with six compartments. Cheung et al. ${ }^{9}$ operated and characterised a staged fixed bed process with three compartments and observed that methanogenic bacteria were predominant at the top. Comparison with non-staged systems was not done and the microbial studies were based on scanning electron microscopy.

In the anaerobic degradation process the organic matter is transformed in methane by a complex sequence of metabolic pathways where the microbial trophic groups are related by their substrate and product specificity. Biomass development and relative bacterial diversity is primarily governed by operating conditions $(\mathrm{pH}$, temperature, waste composition, organic and hydraulic loading rate) which affect the physiological behaviour of bacteria and their physical properties, such as cell mass, size and density of aggregates. ${ }^{10}$ However, reactor design and hydrodynamic behaviour may induce the accumulation of different intermediates, thus affecting the biological and physical properties of microbial aggregates.
The microbial consortia developed in anaerobic digesters can be characterised by several methods, such as direct enumeration, quantification of coenzyme F420 and direct, measurement of methanogenic activity based on methane production. Few of these methodologies are suitable for routine analysis. Typical practical problems associated with some of these techniques include the amount of VSS needed, lack of reliability and reproducibility and time-consumption. ${ }^{11}$ In this work, the biomass developed in a staged upflow anaerobic filter is studied in terms of specific methanogenic activity against acetate, hydrogen, propionate and butyrate. The specific lactose activity is also measured. A control reactor, non-staged, is operated under the same operating conditions for comparative purposes.

\section{MATERIALS AND METHODS}

\subsection{Experimental set-up and operation mode}

The two anaerobic filters (AFI and AFII) were constructed in Plexiglas and are presented schematically in Fig. 1. The initial liquid volume of each reactor was 14.2 and $17.7 \mathrm{dm}^{3}$ for AFI and AFII, respectively. Both configurations had an equal volume of support medium, which consisted of PVC Raschig rings ( $21 \mathrm{~mm}$ in size), with a specific surface area of $230 \mathrm{~m}^{2} \mathrm{~m}^{-3}$ and a porosity of $92.5 \%$. In the staged reactor (AFII), a gas-solid separator was fitted to allow biogas release from each compartment.

The substrate was stored at $4{ }^{\circ} \mathrm{C}$ in order to minimise acidification. Several sampling ports allowed withdrawal of liquid and solid samples. The reactor temperature was kept constant at $35 \pm 1^{\circ} \mathrm{C}$. The seed sludge was obtained from a municipal sewage sludge digester. Both reactors were inoculated with equal

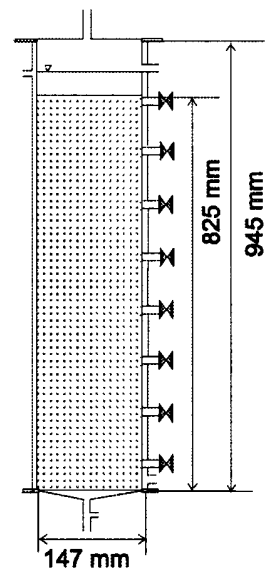

AFI

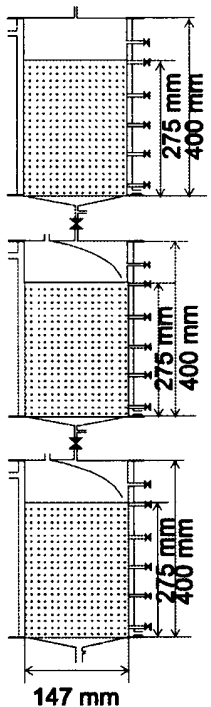

AFII
Fig. 1. Schematic configuration of AFI and AFII. 
amounts of seed sludge $(74 \cdot 2 \mathrm{gVSS})$, but in AFII it was equally distributed among the three stages. Routine reactor performance was monitored by determining influent and effluent chemical oxygen demand (COD), influent flow rate, effluent volatile fatty acids (VFA) (including each stage of AFII), the rate of gas production and its methane content from each reactor (including each stage of AFII). The gas flow rate was measured daily and all the other routine analyses were made three or four times a week. After attaining pseudo-steady state conditions, profiles of COD and volatile fatty acids along the height of each reactor were determined in duplicate. For influent concentrations of

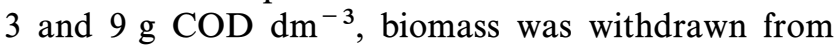
three points in each reactor (first sampling port of each stage of AFII and equivalent points in AFI-located at 5,32 and $65 \mathrm{~cm}$ from the bottom). Sludges were analysed for specific methanogenic activity against acetate, $\mathrm{H}_{2} / \mathrm{CO}_{2}$, propionate and butyrate. The specific rate of lactose consumption was also determined. Tracer experiments were conducted for each operating condition and the flow pattern was determined for both configurations.

\subsection{Substrate}

The substrate was made by dilution of skim milk with tap water and was supplemented with macro- and micronutrients which had the following composition. Macronutrients- $\mathrm{MgSO}_{4} \cdot 7 \mathrm{H}_{2} \mathrm{O}: 30 \cdot 2 \mathrm{~g} \mathrm{dm}^{-3}$; $\mathrm{KH}_{2} \mathrm{PO}_{4}: 28.3 \mathrm{~g} \mathrm{dm}^{-3} ; \mathrm{KCl}: 45 \mathrm{~g} \mathrm{dm}^{-3} ; 0.6 \mathrm{~cm}^{3}$ of this solution was added per gram of COD fed. Micronutrients- $\mathrm{FeCl}_{2} \cdot 6 \mathrm{H}_{2} \mathrm{O}: 2 \mathrm{~g} \mathrm{dm}^{-3} ; \mathrm{H}_{3} \mathrm{BO}_{3}$ : $0.05 \mathrm{~g} \mathrm{dm}^{-3} ; \mathrm{ZnCl}_{2}$ : $0.05 \mathrm{~g} \mathrm{dm}^{-3} ; \mathrm{CuCl}_{2} \cdot 2 \mathrm{H}_{2} \mathrm{O}$ : $0.038 \mathrm{~g} \mathrm{dm}^{-3} ; \quad \quad \mathrm{MnCl}_{2} \cdot 4 \mathrm{H}_{2} \mathrm{O}: \quad 0.5 \mathrm{~g} \mathrm{dm}^{-3}$; $\left(\mathrm{NH}_{4}\right)_{6} \mathrm{Mo}_{7} \mathrm{O}_{24} \cdot 4 \mathrm{H}_{2} \mathrm{O}: 0.05 \mathrm{~g} \mathrm{dm}^{-3} ; \mathrm{AlCl}_{3} \cdot 6 \mathrm{H}_{2} \mathrm{O}$ : $0.09 \mathrm{~g} \mathrm{dm}^{-3} ; \mathrm{CoCl}_{2} \cdot 6 \mathrm{H}_{2} \mathrm{O}: 2 \mathrm{~g} \mathrm{dm}^{-3} ; \mathrm{NiCl}_{2} \cdot 6 \mathrm{H}_{2} \mathrm{O}$ : $0.092 \mathrm{~g} \mathrm{dm}^{-3} ; \quad \mathrm{Na}_{2} \mathrm{SeO}_{3} \cdot 5 \mathrm{H}_{2} \mathrm{O}: \quad 0.164 \mathrm{~g} \mathrm{dm}^{-3}$; EDTA: $1 \mathrm{~g} \mathrm{dm}^{-3}$, Resazurin: $0 \cdot 2 \mathrm{~g} \mathrm{dm}^{-3} ; \mathrm{HCl} 37 \%$ : $1 \mathrm{~cm}^{3} \mathrm{dm}^{-3}$. The composition of this solution was based on the work of Zehnder et al. ${ }^{12}$ Micronutrients were supplemented to the influent feed by addition of $1 \mathrm{~cm}^{3} \mathrm{dm}^{-3}$ of feed.

\subsection{Analytical methods}

\subsubsection{Routine analysis}

Chemical oxygen demand (COD), volatile and total solids (VS and TS) were determined by Standard Methods. ${ }^{13}$ Volatile fatty acids (VFA) were determined by HPLC (Jasco, Japan) using a Chrompack column $(300 \times 6.5 \mathrm{~mm})$ set at $40^{\circ} \mathrm{C}$ and a mobile phase of $5 \mathrm{~mm}$ $\mathrm{H}_{2} \mathrm{SO}_{4}$ at $0.7 \mathrm{~cm}^{3} \mathrm{~min}^{-1}$. The absorption at $210 \mathrm{~nm}$ was measured with a spectrophotometer (Jasco, 870 UV). The methane content of the biogas was measured using a Pye Unicam GCD gas chromatograph
(Cambridge, UK) using a column Chrompack Haysep Q (80-100 mesh). Nitrogen was used as carrier gas $\left(30 \mathrm{~cm}^{3} \mathrm{~min}^{-1}\right)$ and the temperatures of injection port, column and flame ionisation detector were 120, 40 and $130^{\circ} \mathrm{C}$, respectively.

\subsubsection{Activity measurements}

Methanogenic activity was determined using a pressure transducer technique. ${ }^{11,14}$ The pressure increase developed in sealed vials fed with non-gaseous substrates or pressure decrease in vials previously pressurised with gaseous substrates (hydrogen and carbon dioxide $-\mathrm{H}_{2} / \mathrm{CO}_{2} \quad 80: 20 \mathrm{v} / \mathrm{v}$ ) is monitored. Strict anaerobic conditions were maintained. The hand-held pressure transducer used was able to measure a pressure increase or decrease of two atmospheres $(0$ to $\pm 202.6 \mathrm{kPa})$ over a range of -200 to $+200 \mathrm{mV}$. The sensing element is connected to a digital panel module and the device is powered by a $9.0 \mathrm{~V}$ DC transformer. All tests were performed in triplicate. The lactose activity tests were performed by measuring the specific consumption rate of lactose in closed vials. Lactose was analysed by a Boehringer-Mannheim ${ }^{\mathrm{TM}}$ kit.

\subsubsection{Physical characterisation of microbial aggregates}

The settling velocity was determined by measuring the average settling time of the 50 aggregates in a water column.

The size of the microbial aggregates was measured by the projected area using an image analysis system. The images were acquired with a video camera Sony $A V C$ D5CE CCD (Japan) adapted to an Olympus SZ40 (Tokyo, Japan) binocular lens. The 'Image Processing Toolbox' from MATLAB (The Mathworks, USA) was used to perform calculations.

\subsubsection{Tracer experiments}

The residence time distribution (RTD) studies were performed by the stimulus-response technique ${ }^{15}$ using lithium chloride as tracer. An automatic sampler (New Brunswick Scientific, Mx Biosampler, USA) was used to collect and refrigerate samples. Lithium was analysed by flame emission photometry (ATS, 200 MKI, Switzerland). The 'Optimisation Toolbox' from MATLAB (The Mathworks, Inc., USA) was used to obtain the optimal set of parameters by non-linear regression, using the Levenberg Marquardt method. ${ }^{16}$

\section{RESULTS AND DISCUSSION}

\subsection{Reactor performance}

Table 1 summarises the operating conditions and performance data of AFI and AFII. The overall performance of the two reactors was very similar over the 
TABLE 1

Operating Conditions and Performance Data of AFI and AFII

\begin{tabular}{|c|c|c|c|c|c|c|c|c|}
\hline & $\begin{array}{c}\text { Time } \\
\text { (days) }\end{array}$ & $\begin{array}{l}H R T \\
( \pm 0 \cdot 01) \\
\text { days }\end{array}$ & $\begin{array}{c}\text { Influent } \\
\text { COD } \\
\left(m g d m^{-3}\right)\end{array}$ & $\begin{array}{l}\text { Effluent } \\
\text { total COD } \\
\left(m g d m^{-3}\right)\end{array}$ & $\begin{array}{c}\text { Organic loading } \\
\text { rate } \\
\left(k g C O D m^{-3} d a y^{-1}\right)\end{array}$ & $\begin{array}{c}\text { Soluble COD } \\
\text { Efficiency } \\
(\%)\end{array}$ & $\begin{array}{c}\mathrm{CH}_{4} \\
(\%)\end{array}$ & $\begin{array}{c}\text { Methane yield } \\
\mathrm{m}^{3} \mathrm{CH}_{4} \mathrm{~kg} \mathrm{COD}^{-1} \\
\left.\text { removed }^{-1}\right)\end{array}$ \\
\hline \multirow[t]{4}{*}{ AFI } & $343-430$ & 1.93 & $2948 \pm 61$ & $320 \pm 129$ & $1.53 \pm 0.03$ & $97 \cdot 9 \pm 0 \cdot 3$ & $65 \cdot 3 \pm 1 \cdot 0$ & $0.38 \pm 0.03$ \\
\hline & $430-495$ & 1.93 & $5831 \pm 287$ & $572 \pm 173$ & $3 \cdot 02 \pm 0 \cdot 15$ & $97 \cdot 9 \pm 0 \cdot 6$ & $64 \cdot 8 \pm 0 \cdot 6$ & $0.39 \pm 0.04$ \\
\hline & $495-596$ & 1.93 & $8837 \pm 411$ & $973 \pm 217$ & $4.58 \pm 0.21$ & $98 \cdot 2 \pm 0.4$ & $62 \cdot 3 \pm 1 \cdot 3$ & $0.38 \pm 0.03$ \\
\hline & $596-628$ & $1 \cdot 93$ & $12143 \pm 402$ & $2369 \pm 254$ & $6 \cdot 29 \pm 0 \cdot 21$ & $98 \cdot 2 \pm 0 \cdot 2$ & $61 \cdot 1 \pm 0 \cdot 4$ & $0.35 \pm 0.02$ \\
\hline \multirow[t]{4}{*}{ AFII } & $343-430$ & $2 \cdot 05$ & $2952 \pm 60$ & $178 \pm 42$ & $1.44 \pm 0.03$ & $98 \cdot 0 \pm 0 \cdot 3$ & $67 \cdot 0 \pm 6 \cdot 9$ & $0 \cdot 34 \pm 0 \cdot 10$ \\
\hline & $430-495$ & $2 \cdot 05$ & $5831 \pm 287$ & $204 \pm 47$ & $2 \cdot 84 \pm 0 \cdot 14$ & $98 \cdot 8 \pm 0 \cdot 3$ & $64 \cdot 4 \pm 5 \cdot 0$ & $0.35 \pm 0 \cdot 04$ \\
\hline & $495-596$ & $2 \cdot 05$ & $8837 \pm 411$ & $1410 \pm 407$ & $4 \cdot 31 \pm 0 \cdot 20$ & $97 \cdot 9 \pm 0 \cdot 7$ & $61 \cdot 0 \pm 3 \cdot 2$ & $0.33 \pm 0.03$ \\
\hline & $596-628$ & $2 \cdot 05$ & $12143 \pm 402$ & $4506 \pm 1677$ & $5 \cdot 92 \pm 0 \cdot 20$ & $98 \cdot 3 \pm 0 \cdot 5$ & $58 \cdot 4 \pm 1 \cdot 3$ & $0.32 \pm 0.02$ \\
\hline
\end{tabular}

trial period. In AFI the methane yield was higher than in AFII and the effluent volatile solids in AFII, measured by the total effluent COD, increased more than in AFI. This could suggest a shift of COD removal towards biomass production in the staged digester. However the values are not significantly different, considering the associated $95 \%$ confidence intervals.

In the staged digester the contribution of each stage to the biogas production changed along the operation. Initially the first stage produced $73 \%$ of the total biogas, the second stage $20 \%$ and the third stage only $7 \%$. At the end of the trial period the two first stages produced similar volumes of biogas, but the contribution of the third stage was only $11 \%$ (Fig. 2).

For influent concentrations of 3 and $9 \mathrm{~g} \mathrm{COD} \mathrm{dm}^{-3}$, the soluble COD and the COD of volatile fatty acids decreased sharply at the inlet of each reactor and the evolution through the reactors was identical for the two operating conditions (Fig. 3).

However, as can be seen in Fig. 4, the increase in the influent COD altered the aspect of VFA evolution. At an influent COD of $3 \mathrm{~g} \mathrm{dm}^{-3}$, a net decrease of acetic and propionic acids was measured at the bottom of AFI

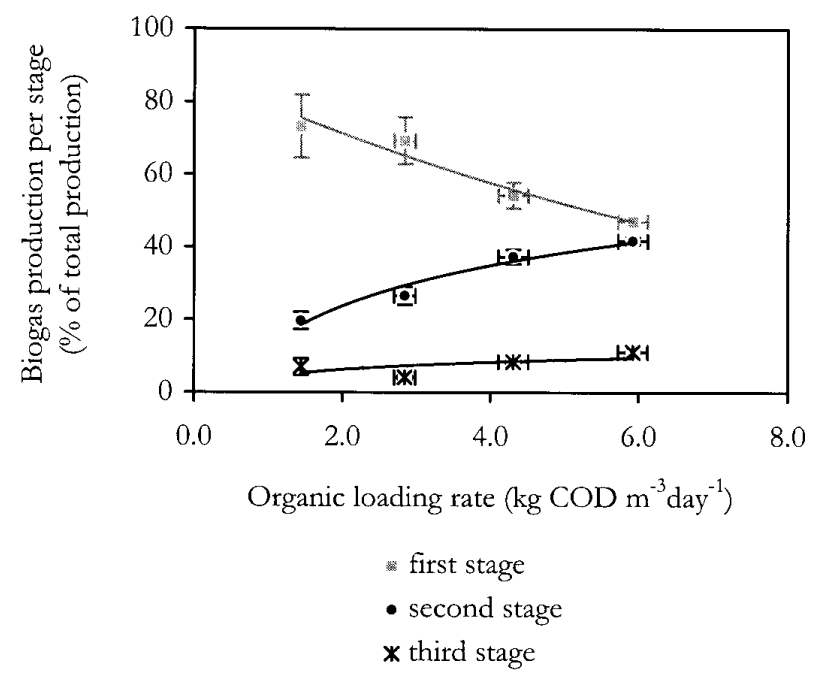

Fig. 2. Contribution of each stage of AFII for the biogas production. and in the first stage of AFII. In the upper sections, practically no VFA were detected in either reactor. This may be explained by the relatively low load applied and by the hydrodynamic behaviour of each configuration. As discussed later, AFI was found to be well mixed in $79 \%$ of its volume, but in the same conditions AFII was less well mixed. At an influent COD of $9 \mathrm{~g} \mathrm{dm}^{-3}$, the bottom of AFI and the first stage of AFII became more acidogenic with a detectable production of acetate and propionate.

Lactate was degraded very quickly in all situations and formate, which was considered by Grobicky and Stuckey $^{3}$ to be an important intermediate formed in the initial compartments of the anaerobic baffled reactor, disappeared close to the inlet of the reactors. This fact may be attributed to the lower loading rates applied and to the lower number of stages in AFII, compared with the baffled reactor studied by these authors.

\subsection{Characterisation of microbial aggregates: activity and physical properties}

Table 2 gives the average volatile solids determined after collection of a representative volume of entrapped solids, and shows the effect of influent concentration on the entrapped VS accumulated in the reactors. For influent concentration of $3 \mathrm{~g} \mathrm{COD} \mathrm{dm}^{-3}$, the ash content was slightly lower in the bottom section, but in the later sections differences were not very significant. At an influent COD of $9 \mathrm{~g} \mathrm{dm}^{-3}$ the ash content increased towards the middle and top sections in both configurations. $\mathrm{pH}$ values were higher in the upper sections, which could explain the presence of a higher content of inorganic solids at the top. Higher values of VS at the top of AFI were observed when compared with AFII but biomass growth was, on average, lower in AFI than in AFII. This reinforces the hypothesis of a shift in COD removal toward biomass production in the staged digester. However, it should be emphasised that these values represent only entrapped biomass. Other experiments using the same support media and 

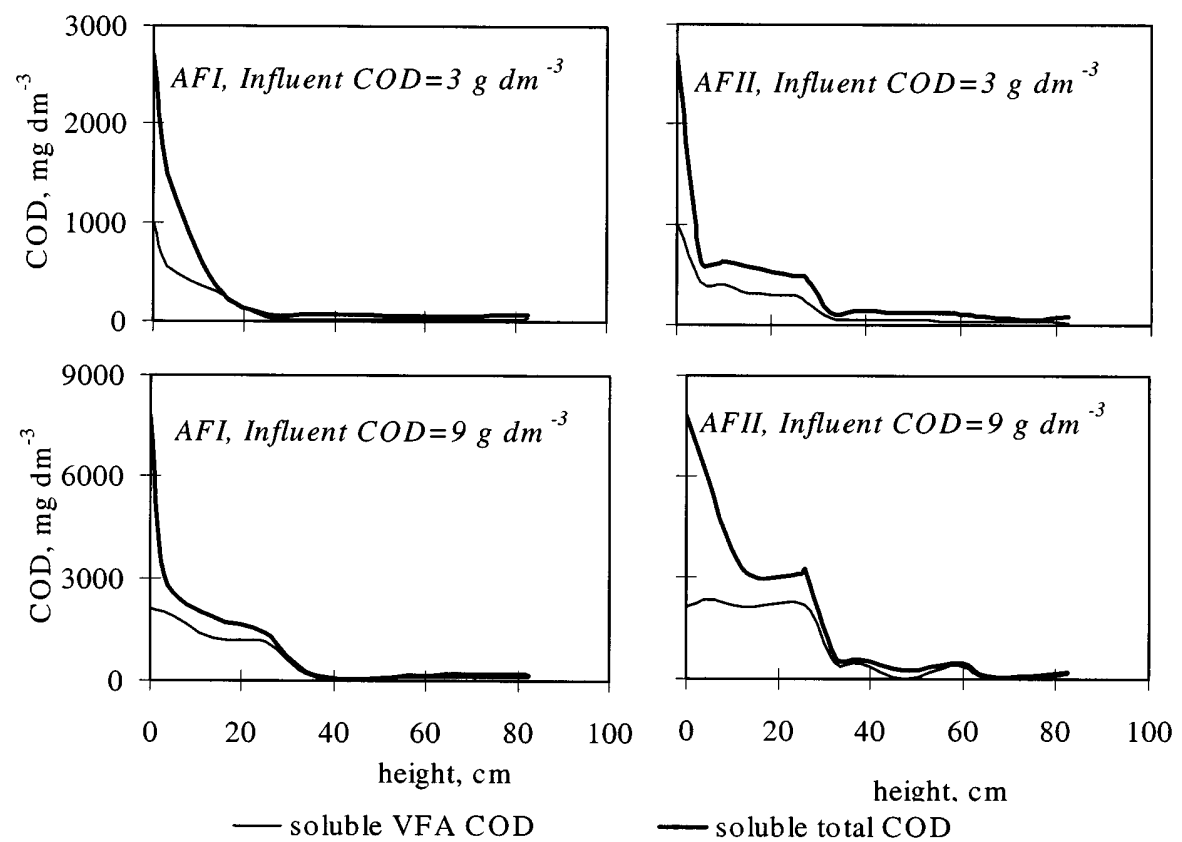

Fig. 3. Soluble COD and VFA-COD along the height of reactors AFI and AFII for influent COD of 3 and $9 \mathrm{~g} \mathrm{dm}^{-3}$.

substrate, but an influent COD of $12 \mathrm{~g} \mathrm{dm}^{-3}$, have demonstrated that the adhered biomass reached $40 \%$ of the total biomass retained in reactors of the configuration under study. ${ }^{17}$

The specific methanogenic activity against direct methanogenic substrates (acetate and $\mathrm{H}_{2} / \mathrm{CO}_{2}$ ) and the specific acidogenic activity against lactose are shown in Table 3 for the two operating conditions tested. At an

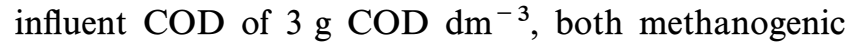
activities were higher for AFII, except in the upper
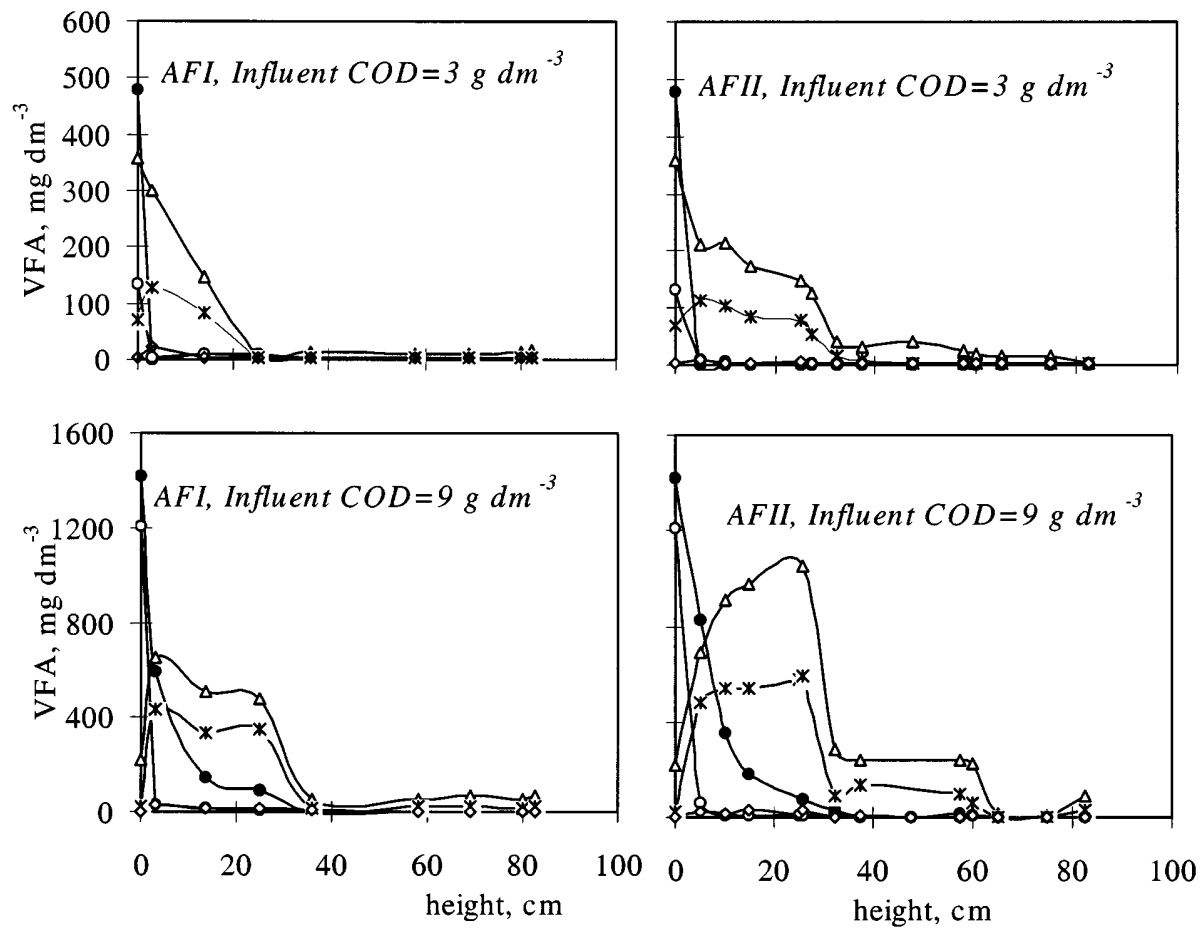

$\rightarrow$ acetic $\rightarrow$ lactic $-*-$ propionic $\multimap-$ formic $\multimap$ butyric

Fig. 4. VFA concentration along the height of reactors AFI and AFII for influent COD of 3 and $9 \mathrm{~g} \mathrm{dm}^{-3}$. 
TABLE 2

Volatile Solids Distribution Along the Height for AFI and AFII

\begin{tabular}{|c|c|c|c|c|c|}
\hline \multirow{2}{*}{$\begin{array}{l}\text { Influent } \\
\text { COD }\left(\mathrm{g} \mathrm{dm}^{-3}\right) \text { : }\end{array}$} & & \multicolumn{2}{|c|}{ Entrapped $V S\left(g d m^{-3}\right)$} & \multicolumn{2}{|c|}{$\% V S / T S$} \\
\hline & & 3 & 9 & 3 & 9 \\
\hline \multirow[t]{4}{*}{ AFI } & Top & $0 \cdot 66 \pm 0 \cdot 01$ & $5 \cdot 22 \pm 0 \cdot 56$ & $73 \cdot 5$ & $59 \cdot 5$ \\
\hline & Middle & $2.95 \pm 0.09$ & $9 \cdot 71 \pm 0 \cdot 19$ & $73 \cdot 7$ & $53 \cdot 6$ \\
\hline & Bottom & $5.02 \pm 0.60$ & $17 \cdot 10 \pm 1 \cdot 04$ & $76 \cdot 9$ & $82 \cdot 7$ \\
\hline & Average & $2 \cdot 88 \pm 0 \cdot 61$ & $10 \cdot 7 \pm 1 \cdot 20$ & & \\
\hline \multirow[t]{4}{*}{ AFII } & Third stage & $0 \cdot 21 \pm 0 \cdot 11$ & $3 \cdot 81 \pm 0 \cdot 04$ & $74 \cdot 4$ & $58 \cdot 7$ \\
\hline & Second stage & $2 \cdot 38 \pm 0.26$ & $17 \cdot 5 \pm 0.04$ & $70 \cdot 2$ & $48 \cdot 9$ \\
\hline & First stage & $5.92 \pm 0.45$ & $16 \cdot 10 \pm 1 \cdot 48$ & $77 \cdot 9$ & $73 \cdot 0$ \\
\hline & Average & $2 \cdot 84 \pm 0.53$ & $12 \cdot 5 \pm 1 \cdot 48$ & & \\
\hline
\end{tabular}

biomass can explain the low value of acetoclastic activity in the first stage of AFII. The acidogenic activity, measured by the activity against lactose, was mainly located at the bottom of each reactor, for an influent COD of $3 \mathrm{~g} \mathrm{dm}^{-3}$. For influent COD of $9 \mathrm{~g} \mathrm{dm}^{-3}$ it was extended to all sections, though the COD and VFA profiles along the height suggest that all the substrate was acidified at the inlet of the third stage of AFII. Higher stratification of the acidogenic activity was observed in AFII than in AFI. The hypothesis of methanogenic activity dilution with acidifying biomass was not observed in the latter sections which were dominated by the growth of methanogenic acetoclastic and hydrogenophilic bacteria. Similarly, the hydrogenophilic activity in AFII's bottom section remained unchanged.

The two genera of acetate-utilising bacteria, Methanosaeta (formerly Methanothrix) and Methanosarcina, differ with respect to substrate affinity, maximum growth rate and substrate specificity. Methanosarcina is able to utilise several substrates, including hydrogen and acetate, whereas Methanosaeta can only degrade acetate. Harper and Pohland ${ }^{18}$ suggested that the multiple substrate utilisation ability of Methanosarcina (Hydrogen Oxidising Acetotroph or HOA) confers a higher survivability on these species. They also commented on the inhibitory effect of hydrogen on acetate degradation by HOA species and on the preference of HOA species for hydrogen over acetate, as confirmed by thermodynamic considerations. These facts suggest that in the first stage of AFII, with an influent COD of $9 \mathrm{~g} \mathrm{COD} \mathrm{dm}^{-3}$, Methanosarcina should be the predominant acetate degrader exhibiting a low acetoclastic activity. On the other hand, in the first stage, the pH values were $6 \cdot 4-6 \cdot 6$, which are beneath the optimal $\mathrm{pH}$ for growth of Methanosaeta.

The specific methanogenic activity against propionate and butyrate is shown in Table 4. Since these are indirect methanogenic substrates, a valid measurement of the maximum specific methanogenic activity against these acids can only be obtained when the acetoclastic and hydrogenophilic activities are not rate-limiting. ${ }^{19} \mathrm{~A}$ comparison of Tables 3 and 4 suggests that this situation prevailed for all samples, with the single exception of biomass removed from the bottom section of AFII at an influent COD concentration of $9 \mathrm{~g} \mathrm{dm}^{-3}$ where the acetoclastic activity was lower than the measured propionate utilising activity.

At an influent concentration of $3 \mathrm{~g} \mathrm{COD} \mathrm{dm}^{-3}$ there was no stratification of propionate activity in both

TABLE 3

Specific Acetoclastic and Hydrogenophilic Activity and Specific Acidogenic Activity on Lactose

\begin{tabular}{|c|c|c|c|c|c|c|c|}
\hline \multirow{3}{*}{\multicolumn{2}{|c|}{$\begin{array}{l}\text { Influent } \\
\text { COD }\left(g \mathrm{dm}^{-3}\right) \text { : }\end{array}$}} & \multicolumn{4}{|c|}{$\begin{array}{l}\text { Specific methanogenic activity against } \\
\left(\mathrm{cm}^{3} \mathrm{CH}_{4} \text { at } \mathrm{STP} \mathrm{g}^{-1} \mathrm{VS} \text { day }^{-1}\right)\end{array}$} & \multicolumn{2}{|c|}{$\begin{array}{c}\text { Specific lactose activity } \\
\text { (mmoles lactose } g^{-1} \text { VS day }{ }^{-1} \text { ) }\end{array}$} \\
\hline & & \multicolumn{2}{|c|}{ Acetate } & \multicolumn{2}{|c|}{$\mathrm{H}_{2} / \mathrm{CO}_{2}$} & \multirow[t]{2}{*}{3} & \multirow[t]{2}{*}{9} \\
\hline & & 3 & 9 & 3 & 9 & & \\
\hline \multirow[t]{3}{*}{ AFI } & Top & $102 \cdot 4 \pm 6 \cdot 2$ & $281 \cdot 1 \pm 5 \cdot 8$ & $1020 \pm 113$ & $1085 \cdot 1 \pm 34 \cdot 1$ & n.d. & $9 \cdot 9 \pm 1 \cdot 5$ \\
\hline & Middle & $127 \cdot 5 \pm 4 \cdot 8$ & $258 \cdot 6 \pm 41 \cdot 1$ & $676 \cdot 9 \pm 8 \cdot 2$ & $819 \cdot 7 \pm 40 \cdot 3$ & $0 \cdot 7 \pm 0 \cdot 1$ & $11 \cdot 0 \pm 1 \cdot 6$ \\
\hline & Bottom & $83 \cdot 0 \pm 9 \cdot 8$ & $171 \cdot 0 \pm 16 \cdot 4$ & $624 \cdot 4 \pm 167 \cdot 6$ & $805 \cdot 6 \pm 35 \cdot 5$ & $5 \cdot 2 \pm 0 \cdot 8$ & $11 \cdot 6 \pm 1 \cdot 7$ \\
\hline \multirow[t]{3}{*}{ AFII } & Third stage & $89 \cdot 8 \pm 12 \cdot 3$ & $255 \cdot 6 \pm 13 \cdot 9$ & $933 \cdot 5 \pm 159 \cdot 4$ & $1030 \pm 108$ & n.d. & $7 \cdot 0 \pm 1 \cdot 1$ \\
\hline & Second stage & $172 \cdot 5 \pm 7 \cdot 5$ & $232 \cdot 9 \pm 19 \cdot 7$ & $907 \cdot 3 \pm 65 \cdot 3$ & $961 \cdot 8 \pm 26 \cdot 0$ & $0.6 \pm 0.1$ & $7 \cdot 8 \pm 1 \cdot 2$ \\
\hline & First stage & $143 \cdot 5 \pm 11 \cdot 6$ & $31 \cdot 6 \pm 10 \cdot 9$ & $819 \cdot 7 \pm 95 \cdot 3$ & $796 \cdot 3 \pm 123 \cdot 1$ & $8 \cdot 0 \pm 1 \cdot 2$ & $11 \cdot 5 \pm 1 \cdot 7$ \\
\hline
\end{tabular}


TABLE 4

Specific Methanogenic Activity Against Propionate and Butyrate

\begin{tabular}{|c|c|c|c|c|c|}
\hline & & \multicolumn{4}{|c|}{$\begin{array}{l}\text { Specific methanogenic activity against } \\
\left(\mathrm{cm}^{3} \mathrm{CH}_{4} \text { at } \mathrm{STP} \mathrm{g}^{-1} \mathrm{VS} \mathrm{day}^{-1}\right)\end{array}$} \\
\hline & & Prol & nate & But & \\
\hline \multicolumn{2}{|c|}{$\begin{array}{l}\text { Influent } \\
\text { COD }\left(g \mathrm{dm}^{-3}\right) \text { : }\end{array}$} & 3 & 9 & 3 & 9 \\
\hline \multirow[t]{3}{*}{ AFI } & Top & n.d. & $85 \cdot 0 \pm 28 \cdot 1$ & n.d. & $6 \cdot 2 \pm 5 \cdot 1$ \\
\hline & Middle & $48 \cdot 8 \pm 3 \cdot 1$ & $151 \cdot 6 \pm 5 \cdot 4$ & $81 \cdot 9 \pm 3 \cdot 04$ & $34.9 \pm 5 \cdot 4$ \\
\hline & Bottom & $58 \cdot 3 \pm 8 \cdot 8$ & $55 \cdot 4 \pm 18 \cdot 0$ & $94 \cdot 8 \pm 10 \cdot 7$ & $1 \cdot 0 \pm 2 \cdot 0$ \\
\hline \multirow[t]{3}{*}{ AFII } & Third stage & n.d. & $93 \cdot 4 \pm 9 \cdot 4$ & n.d. & $14 \cdot 6 \pm 2 \cdot 2$ \\
\hline & Second stage & $100 \cdot 5 \pm 1 \cdot 7$ & $146 \cdot 6 \pm 23 \cdot 2$ & $64 \cdot 3 \pm 6 \cdot 7$ & $13 \cdot 7 \pm 8 \cdot 1$ \\
\hline & First stage & $96 \cdot 2 \pm 13 \cdot 5$ & $37 \cdot 0 \pm 1 \cdot 7$ & $58 \cdot 3 \pm 1 \cdot 7$ & $1 \cdot 5 \pm 5 \cdot 6$ \\
\hline
\end{tabular}

n.d., not determined.

digesters, but, at an influent COD of $9 \mathrm{~g} \mathrm{dm}^{-3}$, a definite maximum was observed in the middle sections, indicating that syntrophic bacteria were predominantly located in these sections. The specific methanogenic activity against butyrate was clearly reduced with the increase in influent concentration. For the non-staged reactor (AFI) and influent concentration of $9 \mathrm{~g} \mathrm{dm}^{-3}$, a net maximum in the middle section was observed. The comparison between the spatial distribution of activity in both configurations (Tables 3 and 4) led to the conclusion that, for the lowest influent concentration tested, no clear stratification of activity was observed. With the exception of the methanogenic activity against butyrate, the staged digesters promoted a more active microbial population. With the increase in substrate concentration, the methanogenic activity against propionate became maximal at the middle sections and acetoclastic and hydrogenophilic activities were predominantly located at the top in both digesters. An evident stratification was observed for the acetoclastic activity in the staged digester.

Guiot et $a .^{10}$ found, in the multiplate anaerobic reactor treating cheese whey effluent, values of specific methanogenic activity between 45 and $270 \mathrm{~cm}^{3} \mathrm{CH}_{4}$ $\mathrm{g}^{-1}$ VSS day ${ }^{-1}$ and between 560 and $1260 \mathrm{~cm}^{3} \mathrm{CH}_{4}$ $\mathrm{g}^{-1} \mathrm{VSS} \mathrm{day}^{-1}$ for acetoclastic and hydrogenophilic activity respectively. For methanogenic activity against propionate they found values between 29 and $98 \mathrm{~cm}^{3}$ $\mathrm{CH}_{4} \mathrm{~g}^{-1} \mathrm{VSS} \mathrm{day}^{-1}$. These values are in the same range of those obtained in the present work.

Table 5 gives the physical properties of the microbial aggregates determined for the same operating conditions. At an influent COD of $3 \mathrm{~g} \mathrm{COD} \mathrm{dm}^{-3}$, the size of the microbial flocs was almost uniform over all the sections, but the increase in influent COD induced their growth especially at the top sections. In the staged digester the size of the aggregates located at the top increased 2.4-fold. By comparing size and settling velocity, it is possible to conclude that the biggest aggregates are less dense than the aggregates present in the middle sections, which are smaller but have a higher settling velocity. A possible explanation is the internal accumulation of biogas in the particles located at the top.

The higher particle density in the middle sections can, in part, explain the maximum methanogenic activity against propionate observed in those points. In fact, it was suggested by Schink and Thauer ${ }^{20}$ that syntrophic associations are favoured by a close physical association

TABLE 5

Size and Settling Velocity of Microbial Aggregates

\begin{tabular}{|c|c|c|c|c|c|}
\hline \multicolumn{2}{|c|}{$\begin{array}{l}\text { Influent } \\
\text { COD }\left(\mathrm{g} \mathrm{dm}^{-3}\right)\end{array}$} & \multicolumn{2}{|c|}{$\begin{array}{l}\text { Size } \\
(\mu m)\end{array}$} & \multicolumn{2}{|c|}{$\begin{array}{l}\text { Settling velocity } \\
\quad\left(m h^{-1}\right)\end{array}$} \\
\hline & & 3 & 9 & 3 & 9 \\
\hline \multirow[t]{3}{*}{ AFI } & Top & $1306 \pm 61$ & $2033 \pm 97$ & $20 \cdot 5 \pm 3 \cdot 1$ & $27 \cdot 5 \pm 4 \cdot 2$ \\
\hline & Middle & $1177 \pm 60$ & $1518 \pm 110$ & $17 \cdot 9 \pm 2 \cdot 2$ & $36 \cdot 6 \pm 6 \cdot 2$ \\
\hline & Bottom & $1580 \pm 79$ & $\simeq^{a}$ & $24 \cdot 5 \pm 3 \cdot 2$ & $\simeq^{a}$ \\
\hline \multirow[t]{3}{*}{ AFII } & Third stage & $951 \pm 56$ & $2248 \pm 215$ & $19 \cdot 9 \pm 2 \cdot 0$ & $27 \cdot 7 \pm 3 \cdot 5$ \\
\hline & Second stage & $1520 \pm 68$ & $2100 \pm 111$ & $26 \cdot 4 \pm 3 \cdot 7$ & $59 \cdot 8 \pm 10 \cdot 4$ \\
\hline & First stage & $1421 \pm 66$ & - $^{a}$ & $29 \cdot 0 \pm 4 \cdot 4$ & $\underline{-}^{a}$ \\
\hline
\end{tabular}

${ }^{a}$ The aggregates were too fluffy, had an undefined size and did not settle. 


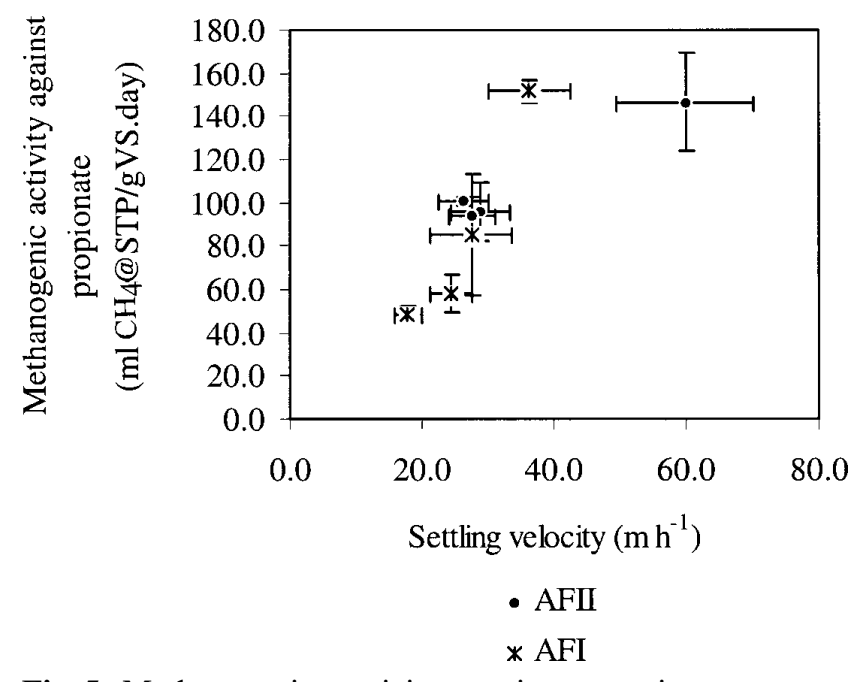

Fig. 5. Methanogenic activity against propionate versus settling velocity of microbial aggregates.

of acetogenic and hydrogenotrophic bacteria. The increasing trend between the methanogenic activity against propionate and the settling velocity, measured for the microbial aggregates present in all the sections of both configurations is presented in Fig. 5.

\subsection{Tracer experiments}

Tracer experiments were performed for influent concentrations of 3 and $9 \mathrm{~g} \mathrm{COD} \mathrm{dm}^{-3}$, in order to evaluate the effect of increasing gas production and biomass in the flow pattern for both reactors. Table 6 represents the results obtained with the application of the 'dispersion model' proposed by Levenspiel. ${ }^{15}$ This is a simple model with a single parameter (Dispersion Number $=D / u L)$ and predicts flow patterns from ideal plug flow (dispersion number $=0$ ) to ideal completely mixed flow (dispersion number $=$ infinite). A value of 0.2 is defined as a large degree of dispersion and 0.02 as an intermediate degree of dispersion.

Although the obtained parameters represent optimal values for each experiment, it can be observed from Table 6 that, in some situations, the correlation coefficient is low, indicating that the dispersion model is not suitable to predict flow in such cases. The multiparameter model proposed by Young and Young ${ }^{21}$ fits well to the experimental data obtained for AFI, for influent concentrations of $3 \mathrm{~g} \mathrm{COD} \mathrm{dm}^{-3}$ (a) and $9 \mathrm{~g}$ COD dm ${ }^{-3}$ (b) (Fig. 6).

TABLE 6

Results of Tracer Experiments. Application of the Dispersion Model

\begin{tabular}{|c|c|c|c|c|c|c|}
\hline & \multicolumn{3}{|c|}{ Influent $C O D=3 \mathrm{~g} \mathrm{dm}^{-3}$} & \multicolumn{3}{|c|}{ Influent $C O D=9 \mathrm{~g} \mathrm{dm}^{-3}$} \\
\hline & $\begin{array}{c}D / u L \\
\text { (correlation coefficient, } R^{2} \text { ) }\end{array}$ & $\begin{array}{l}\text { Recovered } \\
\text { tracer }(\%)\end{array}$ & $\begin{array}{l}M R T \\
\quad(h)\end{array}$ & $\begin{array}{c}D / u \mathrm{~L} \\
\left(\text { correlation coefficient, } R^{2}\right)\end{array}$ & $\begin{array}{l}\text { Recovered } \\
\text { tracer }(\%)\end{array}$ & $\begin{array}{l}M R T \\
\quad(h)\end{array}$ \\
\hline AFI & $\begin{array}{l}0 \cdot 82 \\
(0 \cdot 596)\end{array}$ & $73 \cdot 1$ & $35 \cdot 4$ & $\begin{array}{l}0 \cdot 92 \\
(0 \cdot 858)\end{array}$ & $100 \cdot 6$ & $38 \cdot 5$ \\
\hline AFII & $\begin{array}{c}0 \cdot 15 \\
(0 \cdot 848)\end{array}$ & $93 \cdot 8$ & $55 \cdot 0$ & $\begin{array}{l}0.59 \\
(0.975)\end{array}$ & $109 \cdot 3$ & $42 \cdot 4$ \\
\hline
\end{tabular}

$D$-longitudinal dispersion coefficient, $u$ —superficial velocity, $L$-length; MRT—mean residence time.
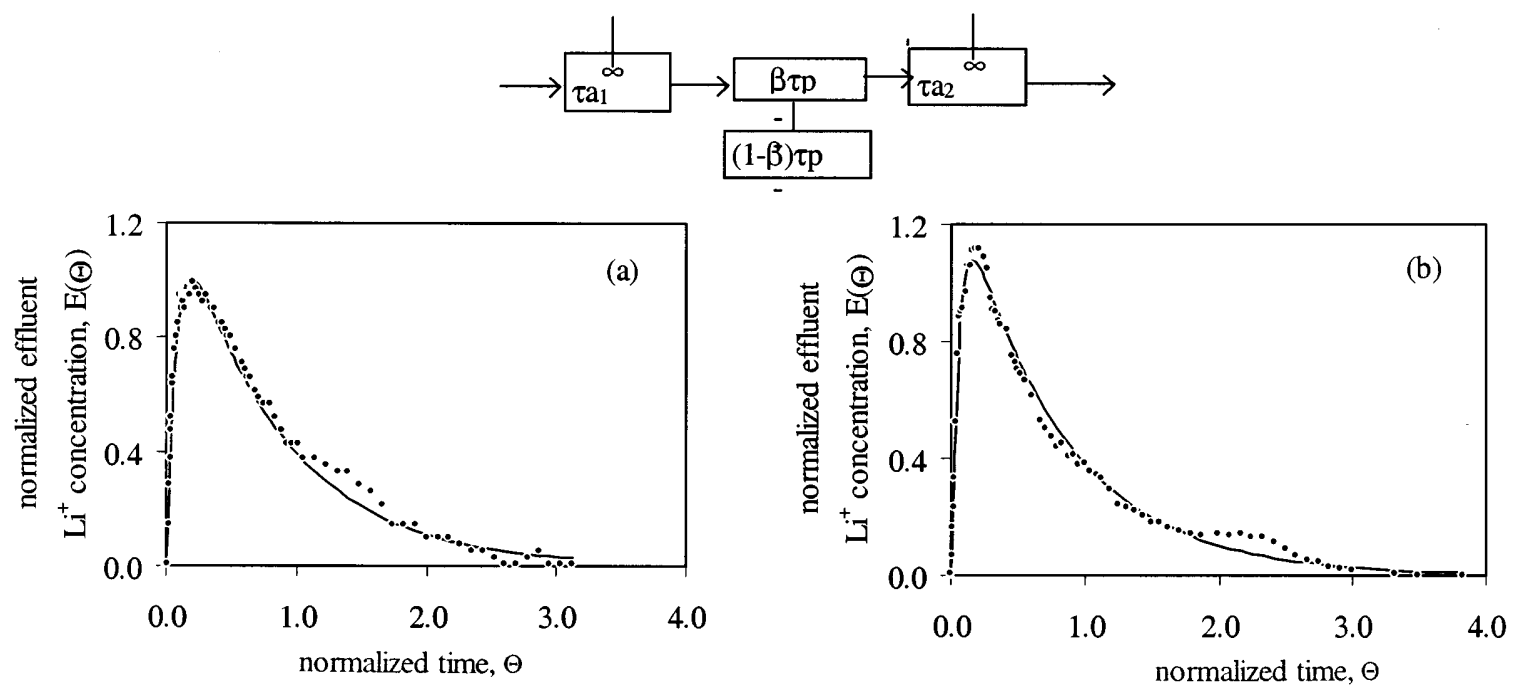

Fig. 6. Application of the model proposed by Young and Young ${ }^{21}$ to the residence time distribution experiment for AFI. (a) Influent COD $=3 \mathrm{~g} \mathrm{dm}^{-3}$. (b) Influent $\mathrm{COD}=9 \mathrm{~g} \mathrm{dm}^{-3}$. 

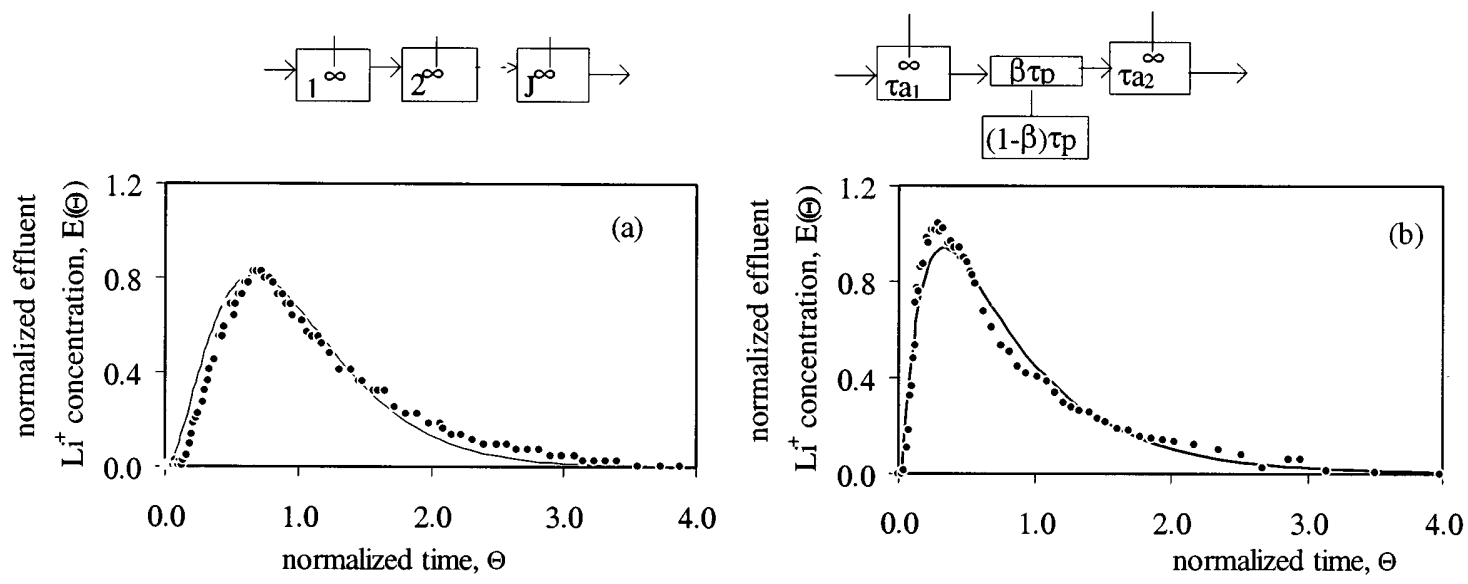

Fig. 7. Application of the 'tanks in series' model and the model proposed by Young and Young ${ }^{21}$ to the residence time distribution experiment for AFII. (a) Influent COD $=3 \mathrm{~g} \mathrm{dm}^{-3}$. (b) Influent COD $=9 \mathrm{~g} \mathrm{dm}^{-3}$.

This model predicts the existence of a completely mixed inlet zone followed by a plug flow volume in parallel with a dead-zone and finally a second completely mixed zone. For AFII and with an influent COD of $3 \mathrm{~g} \mathrm{dm}^{-3}$, a series of three completely mixed volumes described well the flow pattern in this reactor, whereas for influent COD of $9 \mathrm{~g} \mathrm{dm}^{-3}$, the model of Young and Young $^{21}$ was applied with good agreement to the experimental data (Fig. 7).

Table 7 gives the results of the application of the above mentioned models for both configurations. The application of the Young and Young's model ${ }^{21}$ to AFI revealed that the mixed inlet represented $6 \%$ of the total volume, the plug flow was $15 \%$ of the total volume (where there is detectable substrate depletion-Figs 3 and 4 ) and the remaining $79 \%$ of the volume was completely mixed. The dead volume was $14.9 \%$ of the total volume or $96.8 \%$ of the plug flow volume. As observed with the dispersion model (Table 6), no effect of increasing biogas and biomass was detected on the model parameters. This may be explained by the impossibility of distinction between hydraulic and biological dead space with this technique of stimulus-response. It is possible that a shift from hydraulic to biological dead volume had occurred with the increase in influent concentration. Comparison of Fig. 7(a) and (b) suggests that the increase in influent COD increased the amount of dispersion in the staged digester. This was also clear from the application of the dispersion model (Table 6). Furthermore at an influent COD of $9 \mathrm{~g} \mathrm{dm}^{-3}$, the comparison between AFI and AFII flow pattern (Figs 6(b) and $7(b))$ revealed that differences were only marginal. This agrees with the slight differences found for the COD and VFA distributions, microbial segregation and for the performance of the two configurations.

\section{CONCLUSIONS}

For the range of operating conditions tested, there was no clear advantage on the use of staged systems. The stratification of microbial activity increased with the increase in the influent concentration and was more

TABLE 7

Results of Tracer Experiments. Application of the Tanks in Series Model and Young and Young's Model ${ }^{21}$

\begin{tabular}{|c|c|c|c|}
\hline $\begin{array}{c}\text { Digester } \\
\text { Configuration }\end{array}$ & & $\begin{array}{l}\text { Influent COD } \\
\quad 3 \mathrm{gdm}^{-3}\end{array}$ & $\begin{array}{l}\text { Influent COD } \\
\quad 9 \mathrm{gdm}^{-3}\end{array}$ \\
\hline \multirow[t]{5}{*}{ Non-staged (AFI) } & $\tau \mathrm{a} 1 \mathrm{(h)}$ & $3 \cdot 2$ & $2 \cdot 6$ \\
\hline & $\tau \mathrm{p}(\mathrm{h})$ & $6 \cdot 7$ & $7 \cdot 7$ \\
\hline & $\beta$ & 0.032 & $0 \cdot 032$ \\
\hline & $\tau \mathrm{a} 2(\mathrm{~h})$ & $36 \cdot 5$ & $36 \cdot 3$ \\
\hline & Correlation coefficient, $R^{2}$ & 0.983 & $0 \cdot 992$ \\
\hline \multirow[t]{6}{*}{ Staged (AFII) } & $\tau \mathrm{a} 1 \mathrm{(h)}$ & - & $7 \cdot 6$ \\
\hline & $\tau \mathrm{p}(\mathrm{h})$ & - & $9 \cdot 2$ \\
\hline & $\beta$ & - & $0 \cdot 138$ \\
\hline & $\tau \mathrm{a} 2(\mathrm{~h})$ & - & $31 \cdot 2$ \\
\hline & Number of tanks, $J$ & $3 \cdot 0$ & - \\
\hline & Correlation coefficient, $R^{2}$ & 0.923 & $0 \cdot 962$ \\
\hline
\end{tabular}


pronounced in the staged digester. However, for both configurations, the maximum specific acetoclastic and hydrogenophilic activities were observed at the top of the reactors. The specific methanogenic activity against propionate, corresponding to the activity of syntrophic population, was maximal in the middle sections for both configurations and the lactose specific activity was maximal at the bottom. The microbial aggregates present in the middle section were the most dense, which was related to the higher specific methanogenic activity against propionate. Tracer experiments revealed that for the non-staged reactor the flow pattern was unchanged with the increase of influent concentration, whereas for the staged reactor the amount of dispersion detected increased significantly.

\section{ACKNOWLEDGEMENTS}

The financial support of the EU Human Capital and Mobility network Improved Application of Anaerobic Digestion Technology (EXBCHRXCT 930262) and FCT National Programme project number PEAM/ SEL/517/95 are gratefully acknowledged. Image analysis was accomplished using IMAGO, a MATLAB programme written by Luís Amaral and Eugénio Ferreira.

\section{REFERENCES}

1. El-Shafie, A. T. \& Bloodgood, D. E., Anaerobic treatment in a multiple upflow filter system. J. Wat. Pollut. Control Fed., 45 (1973) 2345-57.

2. Harper, S. R. \& Pohland, F. G., Enhancement of anaerobic treatment efficiency through process modification. $J$. Wat. Pollut. Control Fed., 59(3) (1987) 152-61.

3. Grobicki, A. \& Stuckey, D. C., Performance of the anaerobic baffled reactor under steady-state and shock loading conditions. Biotechnol. Bioeng., 37 (1991) 344-55.

4. Van Lier, J. B., Boersma, F., Debets, M. M. W. H. \& Lettinga, G., High rate thermophilic anaerobic wastewater treatment in compartmentalized upflow reactors. Wat Sci. Technol., 30 (1994) 251-61.

5. Guiot, S. R., Safi, B., Frigon, J. C., Mercier, P., Mulligan, C., Tremblay, R. \& Samson, R., Performances of a fullscale novel multiplate anaerobic reactor treating cheese whey effluent. Biotechnol. Bioeng., 45 (1995) 398-405.

6. Lettinga, G., Anaerobic digestion and wastewater treatment systems. Antonie van Leeuwenhoek, 67 (1995) 3-28.

7. Lettinga, G., Hulshoff Pol, L. W., Zeeman, G., Field, J., Van Lier, J. B., Van Buuren, J. C. L., Janssen, A. J. H. \&
Lens, P., Anaerobic treatment in sustainable environmental production concepts. In Proc. 8th Int. Conf. on Anaerobic Digestion, Sendai, Japan, Vol. 1, 1997, pp. 32-9.

8. Van Lier, J. B., Groeneveld, N. \& Lettinga, G., Development of thermophilic methanogenic sludge in compartmentalized upflow reactors. Biotechnol. Bioeng., 50 (1996) 115-24.

9. Cheung, M. Y., Oakley, D. L. \& Forster, C. F., An examination of anaerobic upflow filters operated in a cascade sequence. Environ. Technol. Lett., 7 (1986) 383-90.

10. Morgan, J. W., Evison, L. M. \& Forster, C. F., Changes to the microbial ecology in anaerobic digesters treating ice cream wastewater during start-up. Wat. Res., 25(6) (1991) 639-53.

11. Colleran, E., Concannon, F., Golden, T., Geoghegan, F., Crumlish, B., Killilea, E., Henry, M. \& Coates, J., Use of methanogenic activity tests to characterise anaerobic sludges, screen for anaerobic biodegradability and determine toxicity thresholds against individual anaerobic trophic groups and species. Wat. Sci. Technol., 25 (1992) 31-40.

12. Zehnder, A. J. B., Huser, B. A., Brock, T. D. \& Wuhrmann, K., Characterization of an acetate-decarboxylating, non-hydrogen-oxidizing methane bacterium. Arch. Microbiol., 124 (1980) 1-11.

13. APHA, AWWA, WPCF, Standard Methods for the Examination of Water and Wastewater, 17th edn. Washington, DC, 1989.

14. Coates, J. D., Coughlan, M. F. \& Colleran, E., Simple method for the measurement of the hydrogenotrophic methanogenic activity of anaerobic sludges. J. Microbiol. Meth., 26 (1996) 237-46.

15. Levenspiel, O., Chemical Reaction Engineering. John Wiley, New York, 1972.

16. Marquardt, J. D., An algorithm for least-squares estimation of non-linear parameters. J. Soc. Indust. Appl. Math., 11(2) (1963) 431-41.

17. Alves, M. M., Bellouti, M., Pereira, M. A., Alvares Pereira, M. R., Mota Vieira, J. A., Novais, J. M. \& Mota, M., A new method to study interactions between biomass and packing material in anaerobic fixed bed reactors. Biotechnol. Tech., 12(4) (1998) 277-83.

18. Harper, S. R. \& Pohland, F. G., Recent developments in hydrogen management during anaerobic biological wastewater treatment. Biotechnol. Bioeng., 28 (1986) 585-602.

19. Dolfing, J. \& Bloemen, W. G. B. M., Activity measurements as a tool to characterize the microbial composition of methanogenic environments. J. Microbiol. Meth., 4 (1985) 1-12.

20. Schink, B. \& Thauer, R. K., Energetics of syntrophic methane formation and the influence of aggregation. In Proc. Granular Anaerobic Sludge, Microbiology and Technology (GASMAT) Workshop, eds G. Lettinga, A. J. B. Zehnder, J. T. C. Grotenhuis \& L. W. Hulshoff Pol. Puduc Wagningen, Wageningen, 1987, pp. 5-17.

21. Young, H. W. \& Young, J. C., Hydraulic characteristics of upflow anaerobic filters. J. Envir. Eng. Div. ASCE, 114(3) (1988) 621-38. 